\title{
The long journey to a Systems Biology of neuronal function Nicolas Le Novère*
}

\author{
Address: EMBL-EBI, Wellcome-Trust Genome Campus, CB10 1SD Hinxton, UK \\ Email: Nicolas Le Novère* - lenov@ebi.ac.uk \\ * Corresponding author
}

Published: 13 June 2007

BMC Systems Biology 2007, I:28 doi:10.1 I86/1752-0509-I-28

This article is available from: http://www.biomedcentral.com/1752-0509/I/28

This is an Open Access article distributed under the terms of the Creative Commons Attribution License (http://creativecommons.org/licenses/by/2.0), which permits unrestricted use, distribution, and reproduction in any medium, provided the original work is properly cited.

\begin{abstract}
Computational neurobiology was born over half a century ago, and has since been consistently at the forefront of modelling in biology. The recent progress of computing power and distributed computing allows the building of models spanning several scales, from the synapse to the brain. Initially focused on electrical processes, the simulation of neuronal function now encompasses signalling pathways and ion diffusion. The flow of quantitative data generated by the "omics" approaches, alongside the progress of live imaging, allows the development of models that will also include gene regulatory networks, protein movements and cellular remodelling. A systems biology of brain functions and disorders can now be envisioned. As it did for the last half century, neuroscience can drive forward the field of systems biology.
\end{abstract}

\section{Modelling nervous function, an ancient quest}

Neurosciences have a long and successful tradition of quantitative modelling, where theory and experiment have always formed a happy couple. The work of Warren Sturgis McCulloch and Walter Pitts on formal neural networks [1] gave rise to one of the best examples of cross-fertilising scientific fields, which resulted in many advances both in information technology and cognitive science. Almost as soon as digital computers became available, they were used by neuroscientists to quantitatively test their theories. One of the first numerical simulations in biology was the famous model of Alan Lloyd Hodgkin and Andrew Huxley [2], that explained the propagation of action potentials along axons - and as a by-product postulated the existence of ion channels in the membrane, before the experimental proof of their existence. Quantitatively describing a cellular behaviour emerging from the interaction between two different molecular components, a potassium and a sodium channels, the model of Hodgkin-Huxley can arguably be seen as the beginning of computational systems biology [3].
To accurately model neuronal function presents many challenges, and stretches the techniques and resources of computational biology to their limits. The molecular and cellular events mediating neuronal transmission span several spatial and temporal scales. While the signal received from a glutamatergic terminal is decoded by a 500 nanometer wide dendritic spine [4], the resulting action potential can be propagated along axons up to 1 metre long. Understanding synaptic function also means deciphering the effect of conformational transitions of ion channels, taking place on the microsecond range, onto long-term synaptic modifications lasting several weeks. Moreover, most assumptions used to simplify modelling in other fields of cell biology, such as homogenous concentrations and spatial isotropy are inappropriate. The geometry of subcellular compartments strongly affects their functions [5], as does the relative location of molecular partners and their diffusion. Finally, the morphology of neurons changes over time, and itself depends on the activity of the neurons $[6,7]$ 


\section{Travelling from the ion channel to the brain} With the cable approximation, Wielfrid Rall opened the way to realistic multi-compartment electrical models [8]. This approach assimilates a portion of dendrite to a simple electrical circuit that can then be assembled serially. These models quickly spanned several scales, encompassing synaptic contacts between neurons [9], models of multicellular structures [10], and even of several coupled brain structures [11]. The availability of powerful and easy to use simulators to develop such multi-compartment models, like NEURON [12] and GENESIS [13] allowed the construction of extremely detailed models of neurons. Those models include not only electrical behaviour, but also ion diffusion [14]. Advanced computing facilities now permit the development of large heterogeneous neuronal assemblies, where each neuron possess a realistic geometry and specific electrophysiological properties determined by a given set of ion channels. The most ambitious project in this domain may be the Blue Brain Project [15], which aims to simulate a whole mammalian cerebral cortex using a super-computer. As a proof-of-concept, simulations of a neocortical column containing 10,000 neurons have been run. In parallel to the development of electrical models, neurobiologists started to model neuronal signalling using the concepts of chemical kinetics, already widely used in biochemistry [16]. The coupling of reaction kinetics with single particle diffusion and realistic spatial representation now allows the simulation of neuronal signalling at a level of detail only dreamt of before [17]. At the end of last century, two decades of molecular and cellular neurobiology had demonstrated that to reach a comprehensive understanding of neuronal signalling, we ought to consider both electrical and biochemical signal transduction $[18,19]$.

\section{What are the roadblocks?}

Although computational systems neurobiology is still far ahead of other fields when it comes to multi-scale, multialgorithms modelling, the coupling of signalling pathways, electrical dynamics and ionic diffusion is still infrequent [20]. Even more serious is the fact that some crucial cellular functions or behaviours are barely considered at all when it come to quantitative modelling. Modifications of gene expression [21] and protein translation [22] have been largely studied in synaptic function and plasticity, or in the symptomatology of neuronal diseases [23]. Due to the different time-scales involved, and the difficulty of building hybrid models able to provide continuous descriptions of electrical, metabolic and signalling events together with stochastic or even logical descriptions of gene regulatory networks [24], those aspects of neuronal physiology are mainly considered separately. Cell remodelling has also been generally ignored, whether at the level of the synapse, the spine or the neuronal process, despite an abundant literature showing its importance in neuronal function.

The recent availability of new types of quantitative data should help to expand the models in new directions. On the large-scale front, functional genomics approaches such as microarrays [25] or proteomics [26], but also systematic application of more classical approaches such as in situ hybridization [27] should make the models more accurately reflect brain function and dysfunction. Other cutting-edge technologies like single-particle tracking in living cells [28] will allow the development of more realistic models, and will enable the investigation of the role of micro-domains and supra-macromolecular complexes.

\section{Let's hit the road}

With the general improvement of physical health in developed countries, the relative importance of neuropathology is growing. Mental illnesses are becoming significant public health concerns, schizophrenia, for example, having an incidence approaching $0.5-1 \%$ of the population [29]. The general ageing of the population also increases the incidence of neurodegenerative disorders such as Parkinson's disease, touching more than $1 \%$ after the age of 65 in some countries [30]. Finally, drug addiction, and the associated direct or indirect mortality, remains the most widespread mental disorder and a major worldwide societal problem.

Neurobiology has led the way in computational modelling for over half a century. It is now time to scale up and develop a real systems biology of the nervous system and the associated diseases. The quantitative information is either already available or on its way. Although progress has to be made on the multi-scale and model integration fronts, the methodology is essentially here. The computing power required is matched by the latest generation of super-computers. Neurobiologists have no excuse not to be at the forefront of computational systems biology.

\section{Acknowledgements}

The author thanks Matt Hodgkinson for his help writing this commentary.

\section{References}

I. McCulloch W, Pitts W: A logical calculus of the ideas immanent in nervous activity. Bull Math Biophys 1942, 5: I I5-33.

2. Hodgkin AL, Huxley AF: A quantitative description of membrane current and its application to conduction and excitation in nerve. J Physiol 1952, I I 7:500-544.

3. Levchenko A: Computational cell biology in the post-genomics era. Mol Biol Rep 200I, 28:83-89.

4. Kennedy MB, Beale HC, Carlisle HJ, Washburn LR: Integration of biochemical signalling in spines. Nat Rev Neurosci 2005, 6:423-34.

5. Araya $R$, Jiang J, Eisenthal $K B$, Yuste $R$ : The spine neck filters membrane potentials. Proc Natl Acad Sci USA 2006, 103:17961-17966.

6. Nimchinsky E, Sabatini B, Svoboda K: Structure and function of dendritic spines. Ann Rev Physiol 2002, 64:3 I3-353. 
7. Tada T, Sheng M: Molecular mechanisms of dendritic spine morphogenesis. Curr Opin Neurobiol 2006, 16:95-10I.

8. Rall W: Branching dendritic trees and motoneuron membrane resistivity. Exp Neurol 1959, I:49|-527.

9. Shepherd G, Brayton R: Computer simulation of a dendrodendritic synaptic circuit for self- and lateral-inhibition in the olfactory bulb. Brain Research 1979, 175:377-382.

10. Traub R, Wong RSK: Cellular mechanism of neuronal synchronisation in epilepsy. Science 1982, 216:745-747.

11. Traub R, Contreras D, Cunningham M, Murray H, LeBeau F, Roopun A, Bibbig A, Wilent W, Higley M, Whittington M: Single-column thalamocortical network model exhibiting gamma oscillations, sleep spindles, and epileptogenic bursts. J Neurophysiol 2005, 93:2194-2232

12. Hines M: A program for simulation of nerve equations with branching geometries. Int J Biomed Comput 1989, 24:55-68.

13. Wilson M, Bhalla U, Uhley J, Bower J: GENESIS : A system for simulating neural networks. Advances in Neural Information Processing Systems 1989:485-492.

14. De Schutter E, Smolen P: Calcium dynamics in large neuronal models. Methods in neuronal modeling: from synapses to networks 1997.

15. Markram H: The blue brain project. Nature Rev Neurosci 2006 , 7:153-160

16. Land B, Salpeter E, Salpeter MM: Kinetic parameters for acetylcholine interaction in intact neuromuscular junction. Proc Natl Acad Sci USA 198I, 78:7200-7204.

17. Coggan J, Bartol T, Esquenazi E, Stiles J, Lamont S, Martone M, Berg D, Ellisman M, Sejnowski T: Evidence for Ectopic Neurotransmission at a Neuronal Synapse. Science 2005, 309:446-45I.

18. Bhalla $U$, lyengar R: Emergent properties of networks of biological signaling pathways. Science 1999, 283:38I-387.

19. Kotter R, Schirok D: Towards an integration of biochemical and biophysical models of neuronal information processing: a case study in the nigro-striatal system. Rev Neurosci 1999, 10:247-266.

20. Naoki H, Sakumura Y, Ishii S: Local signaling with molecular diffusion as a decoder of $\mathrm{Ca2}+$ signals in synaptic plasticity. Mol Sys Biol 2005, I:002753-160.

21. Tropea D, Kreiman G, Lyckman A, Mukherjee S, Yu H, Horng S, Sur $M$ : Gene expression changes and molecular pathways mediating activity-dependent plasticity in visual cortex. Nat Neurosci 2006, 9:660-668.

22. Sutton M, Schuman E: Dendritic Protein Synthesis, Synaptic Plasticity, and Memory. Cell 2006, 127:49-58.

23. Benuskova L, Jain V, Wysoski SG, Kasabov NK: Computational neurogenetic modelling a pathway to new discoveries in genetic neuroscience. Int J Neural Syst 2006, 16:215-26.

24. Greene J: Gene expression profiles of brain dopamine neurons and relevance to neuropsychiatric disease. Physiol 2006 , 575:4II-4I6.

25. Su A, Wiltshire T, Batalov S, Lapp H, Ching K, Block D, Zhang J, Soden R, Hayakawa M, Kreiman G, Cooke M, Walker J, Hogenesch J: A gene atlas of the mouse and human protein-encoding transcriptomes. Proc Natl Acad Sci USA 2004, I 0 I:6062-6067.

26. Collins M, Husi H, Yu L, Brandon J. Anderson C. Blackstock W, Choudhary J, Grant S: Molecular characterization and comparison of the components and multiprotein complexes in the postsynaptic proteome. J Neurochem 2006, 97:16-23.

27. Lein E, Hawrylycz M, Ao N, Ayres M, Bensinger A, Bernard A, Boe A, Boguski M, Brockway K, Byrnes E, Chen L, Chen L, Chen T, Chin M, Chong J, Crook B, Czaplinska A, Dang C, Datta S, Dee N, Desaki A, Desta T, Diep E, Dolbeare T, Donelan M, Dong H, Dougherty J, Duncan B, Ebbert A, Eichele G, Estin L, Faber C, Facer B, Fields R, Fischer S, Fliss T, Frensley C, Gates S, Glattfelder K, Halverson K, Hart M, Hohmann J, Howell M, Jeung D, Johnson R, Karr P, Kawal R, Kidney J, Knapik R, Kuan C, Lake J, Laramee A, Larsen K, Lau C, Lemon T, Liang A, Liu Y, Luong L, Michaels J, Morgan J, Morgan R, Mortrud M, Mosqueda N, Ng L, Ng R, Orta G, Overly C, Pak T, Parry S, Pathak S, Pearson O, Puchalski R, Riley Z, Rockett H, Rowland S, Royall J, Ruiz M, Sarno N, Schaffnit K, Shapovalova N, Sivisay T, Slaughterbeck C, Smith S, Smith K, Smith B, Sodt A, Stewart N, Stumpf K, Sunkin S, Sutram M, Tam A, Teemer C, Thaller C, Thompson C, Varnam L, Visel A, Whitlock R, Wohnoutka P, Wolkey C, Wong V, Wood M, Yaylaoglu M, Young R, Youngstrom B, Yuan X, Zhang B, Zwingman T,
Jones A: Genome-wide atlas of gene expression in the adult mouse brain. Nature 2007, 445: I68-176.

28. Groc L, Heine M, Cognet L, Brickley K, Stephenson F, Lounis B, Choquet $\mathrm{D}$ : Differential activity-dependent regulation of the lateral mobilities of AMPA and NMDA receptors. Nat Neurosci 2004, 7:695-696.

29. Goldner E, Hsu L, Waraich P, Somers J: Prevalence and incidence studies of schizophrenic disorders: a systematic review of the literature. Can J Psychiatry 2002, 47:833-843.

30. Zhang ZX, Roman GC, Hong Z, Wu CB, Qu QM, Huang JB, Zhou B Geng ZP, Wu JX, Wen HB, Zhao H, Zahner GE: Parkinson's disease in China: prevalence in Beijing, Xian, and Shanghai. Lancet 2005, 365(9459):595-7.
Publish with Biomed Central and every scientist can read your work free of charge

"BioMed Central will be the most significant development for disseminating the results of biomedical research in our lifetime. "

Sir Paul Nurse, Cancer Research UK

Your research papers will be:

- available free of charge to the entire biomedical community

- peer reviewed and published immediately upon acceptance

- cited in PubMed and archived on PubMed Central

- yours - you keep the copyright 